\title{
YOU CAN BE A MUSEUM OR YOU CAN BE MODERN, BUT YOU CAN'T BE BOTH (Gertrude Stein)
}

\section{Chris Dercon}

In 1974 David Rubin, the then director of the Museum of Modern Art in New York, admitted in an interview that "The Museum concept is not infinitely expandable». He ascribed this to the rupture between the traditional aesthetic categories of painting and sculpture and the earthworks and conceptual art that were all the rage in those days. According to Rubin, this latter group called for an entirely different museum environment and, he added, perhaps a different public too. In saying: "The Museum concept is not infinitely expandable», Rubin was, in my opinion, implicitly referring to the problem of the museum as a public institution.

In 1977, when the Centre Pompidou first opened its doors, the sociologist Pierre Bourdieu prophesied that the desacralization of various items of cultural significance in a desacralized environment with various cultural functions could place the museum in the position of the public institution par excellence. Not only would the traditional aesthetic categories be eliminated, he said, but the perverted image of cultural consumption would also take a turn for the better. The Centre Pompidou too, envisaged 'a different public'; it did not formulate the concept as a problem, however, but as a solution to the essential problem, the problem of the museum.

In 1974 Rubin could not have had the slightest inkling that twenty years later the umpteenth plan to renovate and expand his museum would spark off a discussion which by MOMA standards was quite unusual. Video artist Bill Viola suggested the metaphor for MOMA's future renovation, refurbishment and reorganization: an Internet Website "where you can move vertically and laterally instantaneously across time and space». Not only did the slogan "these collections tell the story of modern art» come under attack, but increasing the visibility of the 'contemporary' should be at the core of the new design, stressing the need for a more experimental space. The new MOMA was going to be a heterotopic museum, a new model with 
32 lots of unprogrammed space. We know by now that this can only mean lots of space for disparate things labelled as visual culture, under the guise of photography, videography, cinematography and, of lots of, to use the trendy word, info-aesthetics. In short, a melange of practices which negate the displays and facilities of the conventional museum.
But for MOMA which has a memorable track record in the field of photography, cinema and video, this foregrounding of the visual virtuality of contemporary media and the attention to cultural multiplicity on a global basis, to name two of the most pregnant characteristics of recent art, is something that is hard to digest. As a result MOMA's university founded a

\section{Chris Dercon \\ - en introduction}

\section{Vibeke Petersen}

Chris Dercon har gennem mange àr varet bidragyder til europaiske kunsttidsskrifter, hvor han har udovet en skarp kritik af samtidskunsten og dens position. Chris Dercon er idag direktor for Museum Boijmans Van Beuningen i Rotterdam. For han kom til museet, var han i 1980'erne leder af udstillingsstedet Witte de With ligeledes $i$ Rotterdam, der er et sted for den eksperimentelle samtidskunst.

I narvarende artikel er Chris Dercons arinde at papege det problematiske forhold, der gor sig galdende omkring det etablerede kunstmuseum og samtidskunstnernes aktiviteter. Han sammenholder Museum of Modern Art, New York, med Centre Pompidou, Paris og Museum Boijmans Van Beuningen for der igennem at påpege hvilke problematikker, der ligger $i$ etableringen af saidanne kunstinstitutioner, og det stadig mere flydende kunstbegreb.

Museum of Modern Art i New York blev etableret i 1929. Museet var det første af sin slags, der udelukkende forholdt sig til vort eget århundredes kunst og som også introducerede en anden form for museumsdrift, hvor der i særlig grad blev lagt vægt på publikums voksende behov for at have mulighed for at kunne tilbringe en mere sammenhængende tid på museet. Etableringen af museumsbutik og museumsrestaurant blev således vigtige aktiver, som var med til at fastholde publikum inden for museets område.

Museum of Modern Art har gennem årene fungeret som model for de mange nyetablerede museer for moderne kunst over hele verden.

Museets samlinger afspejler i dag de mange forskellige medier, som kunstnerne arbejder $i$, og har $i$ allerhøjeste grad været med til at skabe forståelsen for de flydende grænser mellem kunst, kunstindustri og industrielt design.

Centre Pompidou i Paris er en type kunst- og kulturinstitution, som så dagens lys i 1970'erne. Det blev først og fremmest karakteriseret som et kulturhus, hvor der blandt institutionens mange aktiviteter og tilbud til publikum også fandtes en moderne kunstsamling. Kulturhusets identitet lå i at alle typer af aktiviteter blev ligestillet med kunstsamlingen. Tilbuddet til publikum om både fordybelse og adspredelse i den samme institution blev en langt mere sammenhængende del. Det var et $ø$ nske om at etablere en mere demokratisk tilgang til kulturinstitutionerne ved at fokusere på det brede publikums behov og ønsker.

Museum Boijmans Van Beuningen repræsenterer til gengæld den klassiske kunstmuseumsinstitution. Museet har samlinger, der rækker tilbage til 1300tallet og frem til i dag. Museets samlingsomfang 
constituent school in the recent merger with the small, cutting edge P.S.1 in Long Island City, Queens which is an entirely different museum environment with a different public. Just as Rubin had predicted.

In turn, and also twenty years later, Bourdieu and other adherents of the Centre Pompidou were forced to realize that the democratization of high culture

dækker ligesom Museum of Modern Art også kunsthåndværk og industrielt design.

Diskussionen om hvor kunst- og kulturinstitutionen således bevæger sig hen og om denne model kan udvides i det uendelige er absolut til diskussion. Når Chris Dercon tager udgangspunkt i David Rubins udsagn fra 1974, om at kunstmuseet ikke kan udvides i det uendelige, er det netop udfra det synspunkt, at forholdet mellem samtidskunsten og den ældre kunst ikke nødvendigvis er så indlysende et forhold, som vi ofte gerne vil tro. Kunstnernes aktiviteter, som i dag er afledt af en ganske anden kunstpraksis end tidligere, sætter spørgsmål ved, hvorledes vi i vor egen samtid definerer et kunstnerisk udtryk.

Definitionen på et traditionelt værkbegreb er ikke nok i dag. Hvad gør vi med de kunstneriske aktiviteter, som ikke drejer sig om at forholde sig til det gammelkendte kunstobjekt? Er samtidens moderne kunstmuseer overhovedet gearet til at rumme sådanne aktiviteter, der langt mere er knyttet til socioantropologiske undersøgelser? Kunstnerne holder sig ikke tilbage for at udvide deres erfaringsrum. De er blevet et nomadefolk, der via cyber space, uvirkeligt og virkeligt bevæger sig ud $\mathrm{i}$ rummet.

Chris Dercons ærinde er, at både kunst- og kulturinstitutionerne og kunstnerne har en ansvarlighed over for offentligheden. Om vi kan lide det eller ej, er alle involverede parter nødt til at gøre sig overvejelser over, hvilke værdivurderinger vi påfører kunsten, hvorledes vi skaber nye æstetiske kriterier og dermed er med til at ændre vore kulturinstitutioner. was very much a side issue, if not an illusion. The heterogeneity of activities at the Pompidou had failed to overturn the hierarchy of the proffered items of cultural significance. The public was the same public as anywhere else - aficionados of contemporary art rubbing shoulders with library users. However, their numbers had multiplied to such an extent as to impede the development of the activities themselves. The Pompidou's recent renovation and expansion plans bear witness to a far greater compartmentalization and departmentalization than previously, and in the near future activities will be organized in various venues in the city. The glass front which formerly invited exchange was turned into an opaque facade behind which art and culture are disseminated.

Taking MOMA and the Pompidou as our two points of reference, it is interesting to examine the situation at the Boijmans Van Beuningen Museum during the same period, roughly from 1978 to 1996. In the seventies Rotterdam's arts policy focused chiefly on linking welfare and culture. In its simplest form the culturally relativistic message of the postwar social sciences penetrated the formerly closed circles of politicians, policy-makers and other regulators of culture. Such was also the case in Rotterdam. The Bildungsideal envisaged by Wilhelm von Humboldt at the end of the eighteenth century - when high culture was highly rated, so highly that life itself was seen as one long process of education - was replaced by a so-called democratic view of culture. This no longer demanded democratic access to high culture, for in terms of the new creed everything was culture and all forms of culture were equal. 
Director Wim Beeren staved off the imminent threat of a policy fully attuned to a uniform total package for conveying culture. In his opinion the museum's presentation policy should strive to attain a level at which everyone would be able to appreciate the qualitatively exceptional expression of the work of art. He called the art works of Beuys, De Maria, Nauman and Serra and others authentic, personal messages, using autonomy as strategy and as an emancipatory model. The poured concrete floor in the first-floor galleries of the new wing was soon the accepted aesthetic setting for this new approach.

In the eighties, Rotterdam arts policy made an about-turn. Instead of the social and educational attention which had been paid to the art sector up to then, a more businesslike approach was now called for. Art policy came to be increasingly regarded as an instrument that would give the city a new élan and upgrade its image. The eighties saw the gradual emergence of middleof-the-road culture. Cultural legislation was supposed to blindfold itself, meaning that a regatta had about the same chance of being subsidized as museums had.

In his policy note of 1988, director Wim Crouwel expressed his concern that

in this new situation (and in view of the general phenomenon of dwindling government support), the maintenance and improvement of quality and the continuity of the museum's task were expected to require a more businesslike approach.

In addition, the work of art's autonomy was emphasized more strongly than under Beeren, the chief means for conveying artistic values and insights for designer Crouwel and his staff now were to create "good conditions» and a "good context». It was not long before the work of art's autonomy was serving to gloss over the museum's loss of .... autonomy. At the same time the Boijmans Van Beuningen Museum had embarked on an aggressive businesslike course by stressing the importance of the museum restaurant and a museum shop. It was duly decided to enlarge these facilities and relocate them on the street side of the new wing. The public was now ushered into the museum past commercial enterprises. At the same time, sponsors became an important factor in boosting the museum's financial capacity.

All this coincided with what Crouwel called "a shift of interest on the part of the public away from permanent displays towards exhibitions», to which the museum responded with a full programme of temporary presentations both large and small. The various scholarly departments responsible for the growing number of exhibitions, aided by specific budgeting and carrying concomitant budget responsibility, began to function more independently. Acquisition and presentation policy was split up into several parts. Directorial deliberation still took place, but no longer in Beeren's manner. Boijmans became a «multi-faceted" museum, not only in its programme but also in its organization. The Bildungsideal was deliberately and progressively discarded: in the wake of the politicians and policymakers, the museum itself now adopted a pluralistic, pragmatic outlook on culture. Guest curators such as Harald Szeeman, Peter Greenaway and Robert Wilson were invited to illustrate that pluralism, under the guise of 'A Historische Klange'.

A variety of ambient factors began to 
play a part in the nineties. At the beginning of the decade a few institutes of a quite different nature established themselves in the direct vicinity of the Boijmans Van Beuningen Museum: the Witte de With experimental centre for contemporary art, the Kunsthal, the Netherlands Institute of Photography and the V2 experimental centre for new media. As well as enriching the palette, they also held up a mirror to the Boijmans Van Beuningen Museum. What really happened, though, was that the new institutes were mirrored in the bastion of the museum.

The Boijmans Van Beuningen Museum's visitors were the subject of three reports published by Erasmus University in the spring of 1995 . The researchers were struck by the fact that there was no significant rise in numbers between 1988 and 1995, despite the growing number of exhibitions. In one of the reports we read the following recommendation:

The Boijmans Van Beuningen Museum should translate the common points of departure for communication, 'learning/teaching', 'life-enriching' and 'occupying the mind', into a corresponding message. By the same token, the entire 'Boijmans Van Beuningen Museum' should be brought to people's attention. Furthermore, the advantage of this kind of message is that it permits emphasis to be placed systematically on the permanent collections. The universally admired 'multi-faceted' quality of its collections enables the 'indivisible' Boijmans Van Beuningen Museum to offer variation and more completeness than other museums in the Netherlands and Rotterdam. Emphasizing this will prevent a section of the Boijmans Van Beuningen Museum's visitors from transferring their allegiance to other institutes which might cater better to their cultural desires.
These last remarks make it immediately clear that the Boijmans Van Beuningen Museum was gradually being forced into a competitive relationship with neighbouring institutes - the Kunsthal, for example. The original idea had been to build a Kunsthal in Rotterdam so as to divert hordes of blockbuster visitors away from the Boijmans Van Beuningen Museum. The Kunsthal was also seen as a solution to the problem of the space required for such exhibitions. However, things turned out differently than expected when the Kunsthal decided, for budgetary reasons, to pursue an independent course.

It was in this context that the municipal council forced the Kunsthal and the Boijmans Van Beuningen Museum to collaborate in what came to be an unhappy partnership. Today the two institutes go their separate ways. 'Treasures of the Tsar' at the Boijmans Van Beuningen Museum demonstrated yet again the financial benefits of the blockbuster exhibition for a conventional museum, whereas the Kunsthal learned from its exhibition of Pop Art that such presentations are unable to generate a large public for months on end. The Kunsthal has since refused to programme an exhibition of contemporary sculpture from the Boijmans Van Beuningen Museum's collection on the grounds that it "would not attract enough visitors».

The upshot of all this is that the educational aspect has been more or less abandoned in and around the Boijmans Van Beuningen Museum. Numerical supremacy was the message. Instead of propagating a daring, rhetorical vision of culture, the museum was expected to keep in step with the themeless uniformity of media information. 
36 In 1994 the significance of the Kunsthal was the subject of a political debate which prompted the Rotterdam councillor for cultural affairs to invite the Museum Boijmans Van Beuningen to consider plans to extend its complex to a size that would do justice to the collections and programme of activities. The museum we had in mind was first and foremost one in which a distinction would be made between "hordes of visitors» and "a very large number of individual visitors". And an architecture in which improved facilities for that kind of public would receive the same attention as the arrangement of the works of art.

Our idea was to work from the inside towards the outside, from Brueghel's Tower of Babel via Richard Serra's Waxing Arcs towards a big new library which would be the figurehead of the new Boijmans Van Beuningen Museum. Instead of setting our sights on a new and spectacular architecture, we wanted the redesigned building to be a process, a learning process, an instrument which in the hands of museum staff and of external policy-makers would generate change. Only then would our renovation and expansion answer the question about what we actually expected of that multi-faceted, indivisible museum.

On the eve of a new millennium this is a pressing issue, for what will be the place and significance of a museum such as the Boijmans, and indeed of any other museum, in the twenty-first century? In today's culture, moreover, in which the boundary between what are usually referred to as low and high cultures becomes blurred, it is high culture that is principally an unoccupied area. Noone can appropria- te it, but at the same time everybody ought to want to conquer it, and be able to do so. Is the museum then a showcase for art history, or is it a centre for visual culture? Is the museum a buffer against contemporary culture, or a participant in it?

By now it has become clear that progressive as well as more conservative circles are asking the same questions and coming up quite vehemently with the same answers. So vehemently, indeed, that representatives of both the left and right quite often dismiss the rise and fall of the avant garde as a historical mistake. Good riddance to it, they say! But let us not forget that the rise and fall of the avant garde merely reflect the fundamental change in the relationship between art and society, a change brought about by admitting the public into institutes of art. Prior to the period during which art became integrated into social life, there had never been a public for art and hence not for contemporary art either. From the historical point of view, the art public was a gradual phenomenon which has grown explosively since 1960. This is something we have to live with. Not even geniuses like Markus Lüpertz can reverse the process!

There is something else: the layman and not only the layman - makes little or no distinction between the many forms of art production (even if we disregard the flawed visual and linguistic competence of most recent art) and the general visual culture that pervades our immediate surroundings. Much art and many consumer goods are based on the same logic and construction of visual thinking. The museum, then, is no longer an a priori environment. Or is the museum, as Boris Groys puts it, 'the only guarantee for 
making the difference'? A buffer which generates meaning for otherwise meaningless objects?

Moreover, we have come to realise that all the things to be found in the growing number of museums are merely fragments, a small selection from a much larger whole. Every item in a museum space has become a specimen, a piece of evidence. This is turning the real and imaginary space of the museum into almost a virtual space for both the works of art and the public.

One might even go so far as to say that today the museum is partly a representation model in itself. A direct consequence of this is today's spectacular, and above all photogenic museum architecture. In most museums - and this goes for museums of new and old art alike - the temporal environment is gradually being abandoned in favour of architectural signals which prioritize an intense experience of the space. The museum and its objects are being cast further and further adrift from history, lost in an over-aestheticized space, not to mention the magnificent spaces envisaged by artists, curators, politicians and businessmen when they turn their thoughts to a museum. Bilbao's Guggenheim, however strong Gehry's vernacular architecture may be, is based on similar misunderstandings, for instance the misunderstanding that the confrontation of internationalism (read Americanism) and public relations, with a local dynamic creates a rich cultural fabric expressed through the creation of a new museum.

To sum up: the museum's public accessibility is responsible for the fact that it is no longer something «really special». Accessibility has also played a part in turning the museum into a virtual space and a representation machine. How can we then separate care for the work of art from care for the public?

In addition to all this, we must take into account entirely new developments, such as the rise of hypermedia, and the boom in photography and cinematography, which in my view constitute a highly significant aspect of the question of a museum's relationship with the public. Against the background of such new developments, one can only hope that this question will acquire greater topicality. Given collaborative projects between artists in different fields, the expansion of media and new technologies, as well as the desire of many artists and curators alike, to create utilitarian products which can exist in the real world and to participate in a much wider visual debate, there should be at least the possibility of investigating a new museum model. The role of the public is at the core of such an investigation. Do we find these and other concerns reflected in recent designs and extension schemes for museums of art? Hardly.

The outcome of the competition for the New Museum of Modern Art in New York, let alone the recent merger with P.S.1, is typical of the status quo. Instead of picking truly innovative schemes, with a direct impact on the museum activities themselves, such as the ones proposed by architects Rem Koolhaas or Bernard Tschumi, the museum's powerful board decided to go for a safe bet with the modest package-like design of Yoshio Taniguchi. New curatorial ideas, debated so heatedly within the ranks of the Museum of Modern Art, allowing outsiders to have their say as well, seem suddenly to be gone with the wind. The text- 
38 book "Imagining the Future of the Modern of Modern Art", prepared by the Research and Scholarly Publications Program of MOMA, published on the occasion of the design-competition, will be an important source book for anyone trying to write or rewrite the history of the museum. However, it is a book and not a museum.

One might say that popular "alternative museum models» such as the Dia Center for the Arts in New York or the Museum für Moderne Kunst in Frankfurt, praiseworthy as they may be, are by now reflecting ideas of the past rather than the future. Those institutions have clearly chosen an approach where the role of the art and the artist is absolutely central. There is a firm belief, reflected both in the architecture and the activities of these museums, that what is good for the artist might also be good for the public. This is no longer a workable strategy.

The current interest of important architects and other cultural figures for transparency and mobility should indeed also be applied to museum programs and architecture. Good examples do exist. Take for instance Libeskind's exciting Jewish Museum in Berlin or the brilliant Museum for Sculpture/Public Square in Sao Paulo by Paulo Mendes da Rocha. Both buildings, to paraphrase Andrew Benjamin in Present Hope: Philosophy, Architecture, Judaism question display while allowing for display. Benjamin reminds us that Libeskind's building: "guards the question of representation, refusing its finality and thus necessitating its retention as a problem to be investigated, while allowing at the same time for presentations». What has been built, both in Berlin and
Sao Paulo, is indeed a question, while the buildings clearly signal their position of wanting to be a museum (or something else: a monument or a public square).

But where are the clients who dare to commission those architects to design or to extend their museums? The design Herzog \& Demeuron propose for the new Tate Gallery on the South Bank in London, does not go beyond the pivotal pioneering scheme and hierarchy of space both above and below ground which Renzo Piano initiated for the Centre Pompidou. Moreover, their clients and others base their greater sense of a living museum, including praiseworthy initiatives for a greater audience involvement, in principle on methods employed by exemplary international exhibitions over the past ten years. An excellent or challenging exhibition model is not the same as a truly innovative institutional strategy. The investigation of new, institutional models is needed to further develop the meaning of the museum. $\mathrm{Or}$ is the museum concept only expandable on a limited scale?

First there was the encyclopaedia with rows of pictures on a white wall, dedicated to, or legitimized by, chronology and/or style; now, however, the public suddenly becomes aware of a comprehensive museographic project without a real museum environment. An archive in which everyone and everything relies on the latest information techniques whose common feature is that they are image-text systems. The digital modality and especially the binary oppositions on which the database is founded are already responsible for the recent phenomenon that art is hiding behind its antithesis: behind a kind of 
"anthropomorphic fetishism».

In his brilliant essay The Archive Without the Museum the American author Hal Foster, referring to a recent cover of the magazine Art Forum, lists a few examples of this phenomenon: O.J. Simpson, Courtney Love, Broadway Boogie Woogie, Matthew Barney, Prada, Christian de Portzanparc's architecture, Larry Clark, Hugh Grant, Georg Baselitz, Gilbert \& George, Calvin Klein, etc., etc. And indeed, it does not seem all that absurd to maintain that the comparisons which steal their way, cloaked in actuality, into contemporary art shows and publications, are a consequence of the virtual space occupied not only metaphorically but also literally by the museum: film and art, architecture and art, fashion and art. Again, the question of greater public access and public interest in forms of cultural expression figures importantly here. I venture to maintain, however, that this no longer qualifies as a warm gesture towards the public, but that the public itself is claiming its - interactive - rights and is addressing the museum directly.

Be that as it may, it all goes to show that it is not only the museum that divides and conquers, displays and preserves. The museum has become just one of many environments, part of a much bigger museographic project being realised in other places too, from Scalo Verlag to Phaidon Press. By this token the new MOMA's slogan speaks volumes:

The primary reading of the collection will be interrupted at multiple points by alternative readings or opportunities to delve in greater depth into the work of a given artist, period or issue.
One of the great challenges issued by all this, is indeed the notion of reading, of the field of tension generated between image and text, between looking and reading.

People's avid interest in the photo-book provides ample evidence. The numerous exhibitions devoted to photo artists seem to be pilots or advertising campaigns for some publication or other - they all look practically alike - of their works, the illustrations transcending the character of the reproduction. The exhibitions and the exhibits call to mind enlargements and reproductions of the objects in the book. The wheel has come full circle, for are not the discipline of art history and in a sense the museum, too, photography's children?

The museum indeed presents itself as a photographic-cinematographic space. Current interest in photography and cinematography, characteristic of many museums and the problems they are experiencing, highlights the issue of whether we still know what the museum is. I therefore regard the debate on the role of photography and cinematography in the museum as crucial for all deliberations about the museum's future and its relations with the public.

If we are to believe Walter Benjamin, photography is supposed to have put paid to the exhibition effect. Photographs, Benjamin said, should have stayed where they came from: books, magazines, posters, archives. Today we know that things have turned out differently. Perhaps Benjamin had forgotten or underestimated the fact that the mechanical reproducibility of the work of art kept pace with the duplication of the exhibition effect or, rather, with the curious duplication of the 
40 exhibition institute par excellence, the museum. Photography was not only reproducible; it also merited exhibition and was therefore subject to museum law. There are plenty of examples: take the history of MOMA and photography's role in that history. How should photography be displayed, and more importantly, what photography? Still confusion abounds.

We need not search very far afield for an example of this. In the Boijmans Van Beuningen Museum's exhibition Aim Left, meant to evoke the artistic climate in Rotterdam in the 1930s, photographs by Paul Schuitema, Piet Zwart and Wally Elenbaas were «exposed» amidst objects and examples of typography, designed and made by the same artists and kindred spirits. This exhibition effect, this reconstruction, was to no mean extent responsible for preserving the radical quality of the photographs and their continued status as "new Photography». In Boijmans too, framed under glass and accompanied by strains of Berber music in the background, holiday snaps taken by the writer Paul Bowles in Morocco were on show. Not only had his amateurish pictures been enlarged for the occasion: most of them were reproductions, nay, even photographs, of Bowles' originals, destined for a professional publication by a commercial publisher. This is in complete contrast to an exhibition of photography staged at Witte de With, where elegantly framed heliogravures, Muybridge's studies of motion, long since torn from their original albums, were displayed alongside contact prints of working photographs by Jan Dibbets, shown in surprising new combinations as autonomous works of art. And, more recently, at the Boijmans, a series of photographs by the American conceptual artist Chris Williams awakened memories of Renger-Patsch, pioneer of New Photography, and evoked the photographic distance of Neue Sachlichkeit (New Objectivity) once again. But the ontological distinction between photography and painting, the difference between taking pictures and making pictures, was then nullified for the photographs were displayed on large, white walls as if they were precious paintings. Or was this almost theatrical presentation a harbinger of the institutionalisation of photography, of its literal and metaphorical placement/misplacement in the museum?

And what of the exhibition spaces wherein dozens of projected images and many more info pixels, accompanied by oceanic like ambient music or rapid techno beats, consume the viewer's time-log, to such a point that some museums consider handing out free return-passes? Do they not feel like modernist Greenbergian, formalistic, white cubes? Not at all. The only difference is that the white cube has been painted black. Indeed, have any of you recently visited a museum or an exhibition of contemporary art in which one or more white rooms were not darkened? Strangely enough, the architectural program of the European museum of visual culture par excellence, Le Fresnoy in Lille, designed by deconstructivist architect Bernard Tschumi, did not provide enough darkness. So the building has been entirely wrapped in black plastic, turned white by deposits from pigeons! As artist Jeff Wall stated: "The word 'museum' seems to be associated with daylight, whereas the cinema presupposes a dark room. From the beginning, however, the museum claimed 
to be a universal museum. Such a space has to reflect both day and night, so there need to be dark rooms in a museum. Maybe we'll have to think of the solar and the lunar departments of the museum». I'm curious to know if Wall will prove to be right.

In any case, we'll soon have to come up with a museum-architecture which is time-based, preferably defined by individual time rather than collective time. Given recent excellent examples of information-architecture, think for instance of new scientific museums, new libraries or archives, such a new museum typology I guess must be realisable. Yet, none of this has anything to do with the rupture of traditional esthetical categories or criteria, as Rubin feared. It does however concern the question of a museum's intention in collecting, displaying and keeping works of art in general. Omne bonum est diffusivum sui: everything good finds its own place. But what happens when these consequences are no longer effective?

Museums are indeed confronted with another phenomenon which has far reaching consequences for their exhibition and collection policies. Much of the stuff nowadays labelled as art, is not suitable for selection, acquisition, preservation and storage in a museum, at least not in the conventional ways. This development has made itself felt since the early sixties and, going by Rubin's remark «the Museum concept is not infinitely expandable», is now rampant. The effect on the legitimacy of our collections is gradually becoming apparent, at least if we assume that the foremost legitimisation of a collection is to continue to collect, to continue to acquire from what is out there. Indeed, certain 'things' are missing in our museum galleries and storerooms. For the majority of museum people the verdict «it does not fit in our collection" still tends to cover the admission «we don't know how to coop with the stuff”. Such an attitude, adopted by many museum curators and directors, is indeed tantamount to denying and excluding much of the art being produced today.

What would it mean to the museum and especially to the public if the term 'easy to preserve' were replaced by 'hard to reconstruct', as has been the case for hundreds of years in theatres, opera houses and concert halls? The first presentation I initiated as director of the museum Boijmans Van Beuningen was the film installation Four Rotating Walls by Bruce Nauman, a work the Boijmans acquired in 1970 , but had failed to preserve and to show since. So the premiere and restoration of Nauman's pioneering media work occurred only in 1996. Indeed, serious discussions about play and replay, and hence about an archive's status and accessibility, are rarely heard in museum circles. Restoration remains a technical term without ideological content or context.

Many art museums have realised by now that large illuminated photo boxes, slide projections which fade in and out, film projections running in loops, multiple video projections on automatic repeat, or interactive computers linked to the Internet, have liberated their exhibition spaces from the illusion of the static world. Or should we say they have suddenly come to realise that there are static images? Because of new applications for photography, cinema and video, we can 
now really reflect in our museums on what stillness is. From Jeff Wall's point of view, the stillness of still pictures has become very different, otherwise, so he states, one cannot explain the current massive fascination for still photography. In addition, it is the cinema which liberated photography from the rather highbrow orthodox theories of photography and their relation to painting. Photography has renewed itself as an art form through the reflection of, the mediation of, as an explanation of . . . cinematography.

And there is something else. Just as the term 'still life' only came into being at a moment in history when photography was introduced - before that moment one spoke about 'kitchens' or 'banquets' - , art history relied heavily on techniques of photographical reproduction to attract a wide range of objects into a system of style. What then might, as Hal Foster provocatively asked, a digital reordering or digital reproduction underwrite? Art as imagetexts, as info-pixels? An archive without the museum? Art museums have involuntarily liberated themselves from the static world, now they are also forced to get rid of the world of the image itself. If movement was the project of the 20th century, there might be a next project. That project has to be growth, the capacity for an organism to incorporate, which is where intellectual gurus such as Rem Koolhaas and Bruce Mau think cinema and other cultural expressions in their purest sense as an ordering of temporal events, will be left behind.

The moral of this is simple: the primacy of the visual in visual culture may only be apparent. Its new ordering is governed by a digital logic that melts down the logic of word and image, as the computer melted down the photo camera and the film projector. As Hal Foster speculated, at the end of the 20th century art cannot be purified any further, not only in terms of the optical, but also in terms of the informational, due to new developments in photography and cinematography. That is, art cannot be saved any more from its corrupt double: mass culture.

For artists like Hans Haacke, Daniel Buren, John Knight or even David Hammons the museum and its public were and still are something to conquer and to change. For a much younger generation of artists, curators and critics alike, the museum is just one of the many places where art can be shown. Its public is taken for granted.

We often tend to forget that this development is only possible because those who practise 'new ways of making art' have capital available to them other than the capital of the museum, the gallery or the collector. The generosity of this new capital has created a new kind of institutionalization. Within those, so to speak, new institutions, the conventional values of the museum or the gallery, such as authenticity and criticality, return mainly as properties of the site - the choice of a particular neighbourhood, building or other architectural infrastructure - engaged by the artist.

Such displacements are easily marketable - comparisons with the worlds of fashion, design and of course architecture immediately suggest themselves - as well as relatively controllable by and through social and political bodies. Moreover, the object of contestation remains, the institu- 
tion of autonomous art and its thousands of objects or fragments of objects. This fact makes 'new practitioners' - who are often heard publicly stating that one needs 'to connect' - Robin Hoods in the eyes of many, not least those who are unaware of the efforts of, say, the artists mentioned above.

There is little that is new about 'new ways of practising art', in the sense of denying the significance of established institutions, for the museum of (modern) art was born precisely when art was no longer possible. And as $\mathrm{Hal}$ Foster has pointed out, most of the basic assumption of the old productionist model as well as of the legitimation of the avant-garde persists. What is really new is that art has recently begun to look for a global style and discursive form. And it is photography and cinema in particular which function before the other arts as real global media. Photography and cinema do not seem to be limited by different cultural characteristics and art was looking for that. Furthermore, it is now generally agreed that so-called new art practices, such as for instance 'hyper public art' interventions, observations, info aesthetics, etc. in the urban realism - are thought to offer a 'relief', which the autonomous art objects in the museum can not.

As a result, visual art is slowly but steadily vanishing into an expanded field of culture and of other artistic disciplines. The linguistic and visual complexity and competence of the art object can only be diluted by such an 'enthusiastic cultural anthropology of modernity'.

The troubles with the new flexibility, unrestricted curiosity and apparent self- lessness which characterizes so much recent contemporary art are indeed manifold. Not only does the question of value judgement become much less important than ever before, there is also the naive belief that everything good will find its own place. And add to these the fact that many art practitioners aspire to give their work the status of field work, drawing from the start on the basic principles of sociology and anthropology, and we will end up in the realm of knowledge which has hitherto been the province of the social sciences.

There is nothing basically wrong with such rivalry, if only there is some evaluation at work. Instead, though, we are confronted with an endless archive of highly unverifiable observations and theories which hopefully 'might find their own place'. But things go really wrong when the practice stays unnoticed or is only accessible for a select audience. Will this lead to a situation where visual art will no longer be able to shape its own cultural space, thereby invoking not only a pseudology of social sciences but a poor imitation of other art disciplines as well? Is that what we want to achieve?

Of course, it is absolutely true that many artists are using 'new ways of making art', to make truly innovative and invaluable critical works. But I remain sceptical when artists turn their backs on what Thierry de Duve has described as an aesthetic history of art institutions. This not only entails constant comparison and evaluation, but also and primarily the faculty of judging. This right to cast one's vote is not just one of the basic assumptions of our democracies, but of our museum as well. 
All those who practice 'new ways of making art', for instance outside the museum, must allow for situations whereby many people should be able to put themselves in a position in which they can say: this is a significant part, move or step in our culture. That responsibility must be given back to the average viewer, which can never mean just a client, a given community or a select audience. So my call how idealistic this may sound - is a call to reintroduce the right and the capacity to assess - which all cultural producers should nurture and underwrite.

We have to investigate new assessment models in order to confront the changes in the making and the meaning of contemporary art as well as to develop the significance of the art institution itself. Heated discussions about the future of contemporary art and the museum very often tend to stop short at the question of how the existing disciplines and institutions adopt new social and technological developments. What is lacking is a willingness among those concerned to open all the factors to discussion, and if necessary simply to abandon everything in favour of quite different activities. Activities that we would no longer recognize for the domain in which they take place, but the effect that they achieve.

\section{BIBLIOGRAPHY}

Ernst van Alphen, 'Artists as Observing Scientists and Artists as Critical Observers', in Chambres Séparées. Over hedendaagse kunst en macht, Gent (Rijksuniversiteit), 1999

Jean Baudrillard, The Beaubourg Effect: Implosion and

Deference, October no. 20

Andrew Benjamin, Present Hope: Philosophy,
Architecture, Judaism, Routledge, London, 1997

Stefaan Decostere, Chris Dercon, John Wyver, 'The

New Museum', in: Mediamatic, vol. 3\#4, summer 1997

Chris Dercon, Am I Now Getting Sentimental?,

Parkett 33, 1992

Chris Dercon, Business As Usual, Archis no. 10, 1998

Hal Foster, 'The Artist as Ethnographer?', in Global

Visions. Towards a new internationalism in the visual arts, London (Kala Press), 1994

Hal Foster, The Archive Without the Museum, October no. 77, 1996

Hall Foster, Dennis Hollier, Silvia Kolbowski and Rosalind Krauss, The MOMA Expansion: a Conservation with Terence Riley, October no. 84, 1998

Boris Groys, Kunst im Museum, lecture delivered at Basel Museum für Gegenwartskunst, 1998, unpublished paper

Boris Groys, The Restoration of Destruction, Witte de With, Cahiers no. 4, Rotterdam «Imagining the Future of Modern Art", in Studies in Modern Art, Research and Scholarly Publications Program of MOMA New York, no. 7, 1997

Rosalind Krauss, The Cultural Logic of the Late Capitalist Museum, October 1990

Donald Preziosi, Avoiding Museocannibalism, catalogue XXIV Bienal de Sao Paulo, 1998

Donald Preziosi, Brain of the Earth's Body: Museums of the Fabrication of Modernity, unpublished paper Deutscher Kunsthistoriker Tag Technische Universität München, 1997

Gianni Vattimo, Ort Möglicher Welten zurRolle des Museums in der Postmoderne, Lettre International, no. 1,1997

Chris Dercon is director of Museum Boijmans Van Beuningen

Adr. Museum Boijmans Van Beuningen

Museumpark 18-20 3015 CX Rotterdam, The Netherlands 